\title{
Phytochemical capacity of Nitraria retusa leaves extracts inhibiting growth of melanoma cells and enhancing melanogenesis of B16F10 melanoma
}

\author{
Jihed Boubaker ${ }^{1,2,3^{*}}$, Imen Mokdad Bzeouich ${ }^{1,2}$, Nouha Nasr ${ }^{1,2}$, Hajer Ben Ghozlen ${ }^{1,2}$, Nadia Mustapha ${ }^{1,2}$, \\ Kamel Ghedira ${ }^{2}$ and Leila Chekir-Ghedira ${ }^{1}$
}

\begin{abstract}
Background: Here, phytochemical profile of Nitraria retusa (N. Retusa) leaf extracts was identified and their ability to induce apoptosis and inhibiting growth of melanoma cells and enhancing melanogenesis of B16F10 melanoma was evaluated.

Methods: The Apoptosis was evidenced by investigating DNA fragmentation, and Acridine orange/ethidium bromide staining. Amounts of melanin and tyrosinase were measured spectrophotometrically at $475 \mathrm{~nm}$.

Results: Extracts from Nitraria retusa exhibited significant anti-proliferative activity after $48 \mathrm{~h}$ of incubation. Our result was confirmed by ladder DNA fragmentation profile. All extracts showed also the ability to enhance melanogenesis and tyrosinase activity of B16F10 melanoma cells.
\end{abstract}

Conclusion: The tested extracts have a significant biological effect which may be due to their bioactive compounds.

Keywords: Bioactive compounds, B16F10, Apoptosis, Melanogenesis, Tyrosinase, Flavonoids, Polyphenols

\section{Background}

Traditional herbs and plants are widely used for their properties [1], Consequently, research interest in the use of natural products, such as chemical extracts from medicinal plants, herbs, and spices, for the development of alternative chemotherapeutic agents [2] food additives and cosmetic products is considerable $[3,4]$.

In fact, the World Health Organization (WHO) has emphasized the importance of the traditional indigenous medicines, since a large majority of rural people in the developing countries still use these medicines as the first defence in health care [5].

It was also reported that a high number of new drugs deriving from plant secondary metabolites have been used in the treatment and/or prevention of cancer. For example the antiproliferative activity of flavonoids, polyphenols and

\footnotetext{
* Correspondence: jihed.boubaker@yahoo.fr

'Laboratory of Cellular and Molecular Biology, Faculty of Dental Medicine,

University of Monastir, Rue Avicenne, Monastir 5000, Tunisia

${ }^{2}$ Unity of bioactive natural substances and biotechnology, Faculty of

Pharmacy, University of Monastir, Rue Avicenne, Monastir 5000, Tunisia

Full list of author information is available at the end of the article
}

sterols against cancers cells was demonstrated by many researchers [6-8].

In this context melanoma is the most aggressive forms of skin cancer, with high metastatic potential and extraordinary resistance to cytotoxic agents [9] and it is resistant to all current modalities of cancer therapy. Drug resistance in melanoma is associated with defects in the apoptotic programme.

In fact some secondary metabolites have been found to suppress growth and proliferation of transformed or malignant cells through induction of programmed cell death or apoptosis [10,11]. Alesiani et al. [12] demonstrated that melanoma population growth reduction was linked to differentiation processes detected by monitoring some specific markers like melanine synthesis. That's why we undertook in this study the effect of Nitraria retusa leaf extracts on proliferation and melanogenesis of B16F10 melanoma cells.

In our case, we were interested in the leaf extracts of Nitraria retusa in order to investigate alternative phytotherapy solutions to current anticancer treatments and preventing cancer development. 


\section{Methods}

\section{Plant material and preparation of extracts}

Leaves of $N$. retusa were collected from saline soils in Sahline, a region situated in mid-Tunisia, in December 2006. Their identification was done by Pr. M. Cheieb (Departmentof Botany, Faculty of Sciences, University of Sfax, Tunisia), according to the Flora of Tunisia [13, 14]. A voucher specimen (N.r-12.06) has been kept in our laboratory for future reference. The leaves were hade dried, powdered, and stored in a tightly closed container for further use. Three hundred and fifty grams of powder, from dried leaves, were sequentially extracted in a Soxhlet apparatus (6 h) (AM Glassware, Aberdeen, Scotland, United Kingdom) with hexane, chloroform, ethyl acetate and methanol solvents. We obtained the correspondent extracts for each solvent. Hexane (Hex), chloroform (Chl) and methanol $(\mathrm{MeOH})$ extracts, with different polarities, were concentrated to dryness and the residues were kept at $4{ }^{\circ} \mathrm{C}$. Then, each extract was resuspended in dimethyl sulfoxide solvent (DMSO). Plant materials were screened for the presence of tannins, flavonoids, coumarins and sterols using the methods previously described by Boubaker, et al. [15].

\section{Cell line and culture}

The B16F10 melanoma line was obtained from American Type Culture Collection (ATCC, Manassas, VA) and maintained at $37{ }^{\circ} \mathrm{C}$ in a humidified incubator with $5 \%$ $\mathrm{CO}_{2}$ at $37{ }^{\circ} \mathrm{C}$, and grown. The cells were culture in RPMI-1640 medium supple- mented with $10 \%$ (v/v) fetal calf serum (FCS, Biowhitaker, Lonza, Belgium), $2 \mathrm{mM}$ glutamine, $1 \%$ NEA (100X), $1 \%$ sodium pyruvate $100 \mathrm{mM}$ (complete RPMI).

\section{Assay for cytotoxic activity}

Cytotoxicity of Nitraria retusa extracts against B16F10 cells was estimated by the 3-(4,5-dimethylthiazol-2-yl)2,5-diphenyltetrazolium bromide (MTT) assay, based on the reduction of the MTT by mitochondrial dehydrogenases in viable cells. The resulting blue formazan product is measured spectrophotometrically [16]. Cells were seeded in a 96-well plate at a concentration of $5 \times 10^{3}$ cells/well and incubated at $37{ }^{\circ} \mathrm{C}$ for $24 \mathrm{~h}$ in a $5 \% \mathrm{CO}_{2}$ enriched atmosphere. The extracts were firstly dissolved in $1 \% \mathrm{DMSO}$, then in the cell growth medium. Cells were incubated again at $37{ }^{\circ} \mathrm{C}$ for $48 \mathrm{~h}$ with each of the tested extract at concentrations ranging from 10 to $1000 \mu \mathrm{g} / \mathrm{ml}$. Next, the medium was removed and cells in each well were incubated with $50 \mu \mathrm{l}$ of MTT solution $(5 \mathrm{mg} / \mathrm{ml})$ at $37{ }^{\circ} \mathrm{C}$ for $4 \mathrm{~h}$. MTT solution was then discarded and $50 \mu \mathrm{l}$ of $100 \%$ DMSO were added to dissolve the insoluble formazan crystal. The optical density was measured at $540 \mathrm{~nm}$. Each drug concentration was tested in triplicate.
The cytotoxic effects of the extracts were estimated in terms of cell population growth inhibition percentage and expressed as $\mathrm{IC}_{50}$ which is the concentration of extract that reduces the absorbance of the treated cells by $50 \%$ with reference to the control (cells treated with $\mathrm{DMSO}$ ). The $\mathrm{IC}_{50}$ values were graphically obtained from the dose-response curves. We determined $\mathrm{IC}_{50}$ values when cytotoxicity resulted more than $50 \%$ at screening concentrations.

\section{DNA fragmentation analysis}

DNA fragmentation was analysed by agarose gel electrophoresis as described by Wang et al., [17], with slight modifications. B16-F10 cells $\left(1.510^{6}\right.$ cells $\left./ \mathrm{ml}\right)$ were exposed to various concentrations of each compounds $\left(\mathrm{IC}_{50}, \mathrm{IC}_{50}\right.$ and $\mathrm{IC}_{50} \mu \mathrm{g} / \mathrm{ml}$ of $\mathrm{Hex}, \mathrm{Chl}, \mathrm{EA}$ and $\mathrm{MeOH}$ extracts) for $48 \mathrm{~h}$ and harvested by centrifugation. Cell pellets were resuspended in $200 \mu \mathrm{l}$ of lysis buffer (50 mM Tris- $\mathrm{HCl}, \mathrm{pH}$ 8.0, 10 mM EDTA, $0.5 \% \mathrm{~N}$ Lauroyl Sarcosine Sodium Salt) at room temperature for $1 \mathrm{~h}$ then centrifuged at $12000 \mathrm{~g}$ for $20 \mathrm{~min}$ at $4{ }^{\circ} \mathrm{C}$. The supernatant was incubated overnight at $56{ }^{\circ} \mathrm{C}$ with $250 \mu \mathrm{g} / \mathrm{ml}$ proteinase $\mathrm{K}$. Cell lysates were then treated with $2 \mathrm{mg} / \mathrm{ml} \mathrm{RNase} \mathrm{A}$ and incubated at $56{ }^{\circ} \mathrm{C}$ for $2 \mathrm{~h}$. DNA was extracted with chloroform/phenol/isoamyl alcohol $(24 / 25 / 1, v / v / v)$ and precipitated from the aqueous phase by centrifugation at $14000 \mathrm{~g}$ for $30 \mathrm{~min}$ at $0{ }^{\circ} \mathrm{C}$. The DNA solution was transferred to $1.5 \%$ agarose gel and electrophoresis was carried out at $67 \mathrm{~V}$ for $3 / 4 \mathrm{~h}$ with TAE (Tris $40 \mathrm{mM}$, sodium acetate $20 \mathrm{mM}$, EDTA $1 \mathrm{mM})$ as the running buffer. DNA in the gel was visualized with ethidium bromide $(0.5 \mu \mathrm{g} / \mathrm{ml})$ under UV light.

\section{Acridine orange $(\mathrm{AO})$ /ethidium bromide (EB) staining}

Cells were cultured in 6-well plate then treated by all concentration of tested extract of Nitraria retusa leaves. After $24 \mathrm{~h}$ of incubation, cells were collected and washed with PBS followed by staining with 1:1 mixture of $\mathrm{AO} / \mathrm{EB} 5100 \mu \mathrm{g} / \mathrm{ml}$ stock). Stained nuclei were visualized under a fluorescence microscope [18].

\section{Determination of melanin content}

Melanin release by cells was measured as described in Skandrani et al. [19] with some modifications. Briefly, B16-F10 cells $\left(510^{5}\right)$ were seeded into a $25-\mathrm{cm}^{2}$ culture flask with $5 \mathrm{ml}$ culture medium and incubated at $37 \mathrm{C}$ for $24 \mathrm{~h}$. The cells were then treated with $\mathrm{G}$ extract for $48 \mathrm{~h}$. After treatment, melanogenesis (clo- sely related to amont of melanin produced) was estimated from the amount of melanin retained in the cells (intracellular melanin). Adherent cells were detached by incubation in trypsin; $510^{5}$ cells were then placed in tubes and solubilized in $1 \mathrm{ml}$ Triton X-100 (0.1\%). 
Table 1 Quantitative phytochemical screening of extracts from Nitraria retusa leaves

\begin{tabular}{lllll}
\hline & Hex & Chl & EA & MeOH \\
\hline Equivalent concentration of gallic acid $(\mu \mathrm{g} / \mathrm{ml})$ & - & $100 \pm 3$ & $66.25 \pm 3$ & $30 \pm 4$ \\
Equivalent concentration of Quercétine $(\mu \mathrm{g} / \mathrm{ml})$ & - & - & $193.33 \pm 5$ & $146,52 \pm 5$ \\
Tanins $(\mathrm{mg} / 100 \mathrm{~g})$ & - & - & $2.26 \pm 0.5$ & $1,88 \pm 3$ \\
Sterols $(\%)$ & 31 & 10.75 & $8.68 \pm 0.01$ & - \\
\hline
\end{tabular}

Values represent the mean +-SD of three separate experiments

The absorbance (reflecting intracellular melanin content) for each sample was subsequently measured at Scientific, Madison, WI).

\section{Tyrosinase activity}

Tyrosinase enzyme activity was estimated by measuring rate of L-3,4 dihydroxyphenylalanine (L-DOPA) oxidation, as described previ- ously (Skandrani et al. [19] with slight modification. Briefly, cells $\left(5 \times 10^{5}\right)$ were treated with $\mathrm{Hex}, \mathrm{Chl}, \mathrm{EA}$, and $\mathrm{MeOH}$ extracts of Nitraria retusa $(340,80,50$ and $100 \mu \mathrm{g} / \mathrm{ml}$ respectively) for $48 \mathrm{~h}$, $10^{6}$ cells were then resuspended in phosphate buffer (0.1 M; pH 6.8) containing $0.1 \%$ Triton $\times 100$. Lysate was clarified by centrifugation at $17,500 \mathrm{~g}$ for $10 \mathrm{~min}$ at $4{ }^{\circ} \mathrm{C}$; $400 \mu \mathrm{l}$ of supernatant was mixed with $400 \mu \mathrm{l}$ of the substrate L-DOPA (0.15\%), and absorbance was measured spectrophotometrically at $475 \mathrm{~nm}$, every minute for $10 \mathrm{~min}$.

\section{Statistical analysis}

Data were collected and expressed as the mean \pm standard deviation of 3 independent experiments and analyzed for statistical significance from control. The data were tested for statistical differences by one-way ANOVA followed by student test using statistica. The criterion for significance was set at $P<0.05$.

\section{Results}

Phytochemical study and determination of extract yield, total polyphenol, flavonoid, tannin and sterol contents of Nitraria retusa leaf extracts

The highest content of polyphenols was recorded in Chl extract $(100 \mu \mathrm{g} / \mathrm{ml}$ Equivalent concentration of gallic acid). The Hex extract showed the presence of an important quantity of sterols equivalent to $31 \%$. Whereas, $\mathrm{MeOH}$ and EA extracts exhibited the highest quantities of flavonoids respectively $(146,52 \mu \mathrm{g} / \mathrm{ml}$ and $193.33 \mu \mathrm{g} / \mathrm{ml}$ concentration equivalent quercetin) (Table 1).

\section{Cytotoxic activity}

We have examined the effect of different concentrations (from 10 to $1000 \mu \mathrm{g} / \mathrm{ml}$ ) of each extract on the B16-F10 cell population growth in-vitro, using the MTT assay. The results of this assay were reported in (Fig. 1). EA, $\mathrm{Chl}$, Hex and $\mathrm{MeOH}$ extracts inhibited significant the malignant tested cell population growth. ( $\mathrm{IC}_{50}$ values were $50,80,340$ and $>1000 \mu \mathrm{g} / \mathrm{ml}$ respectively) (Fig. 1).

Induction of apoptotic DNA fragmentation by Nitraria retusa extracts on leukemia cells

At exposure with different concentrations of Hex extract (Fig. 2, tracks b, c, d), Chl extract (Fig. 2, tracks e, f, g), EA extract (Fig. 2, tracks h, i, j) and $\mathrm{MeOH}$ extract (K,L,M) during $48 \mathrm{~h}$, a fragmented DNA profile was clearly observed in B16-F10 cells treated with $\mathrm{Chl}$ and

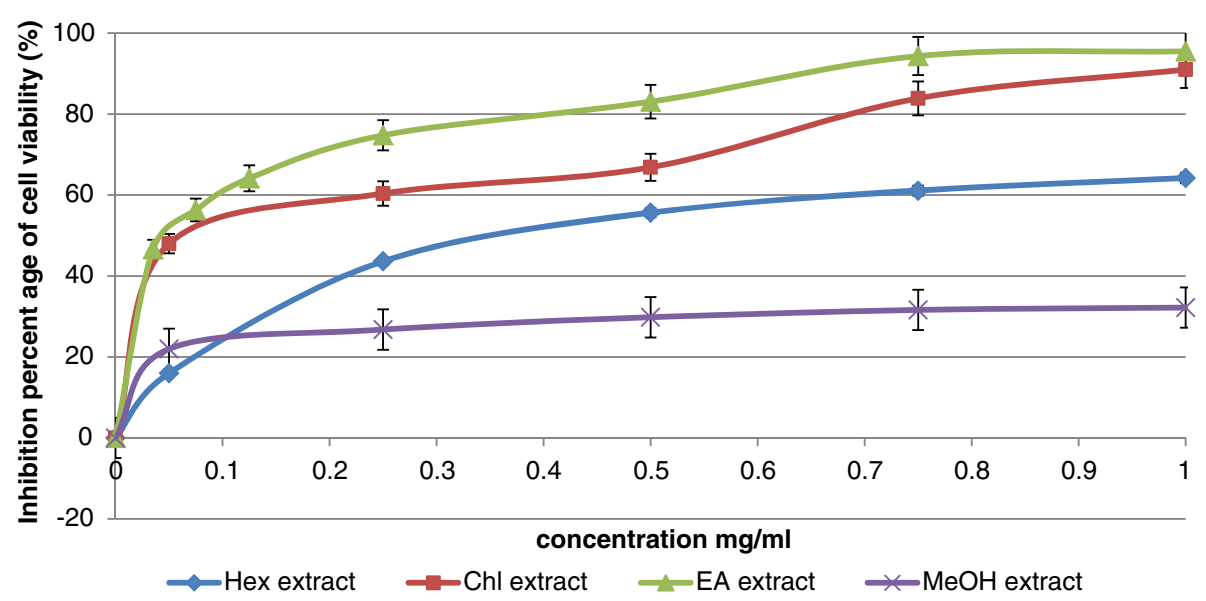

Fig. 1 Anti-proliferative effect of Nitraria retusa extracts on B16-F10 melanoma cells. Values represent the mean \pm SD of three separate experiments 


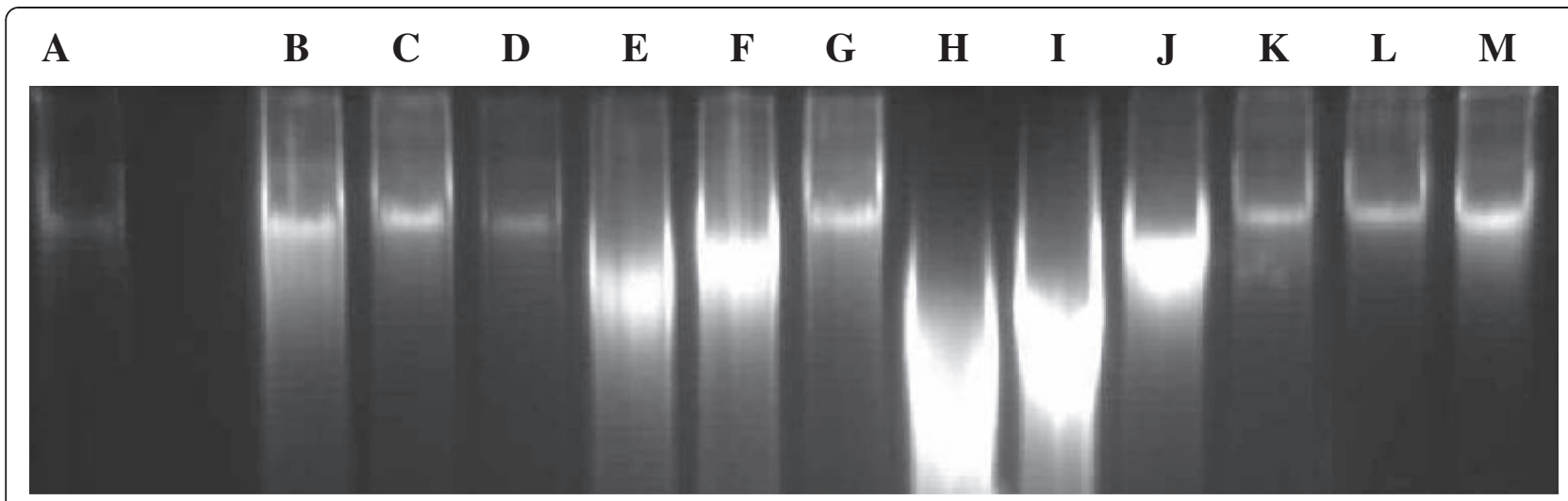

Fig. 2 DNA electrophoretic profiles of B16-F10 cells treated with different concentrations of Hex (hexane), Chl (chloroform), EA (ethyl acetate) and $\mathrm{MeOH}$ (methanol) extracts during $48 \mathrm{~h} \mathrm{~h}$. DNA was separated on $1.5 \%$ agarose gel. a PC: B16-F10 cell DNA; DNA of cells treated with b Hex

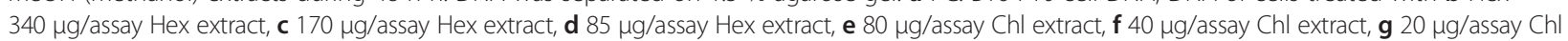

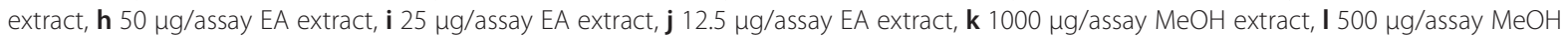
extract, m $250 \mu \mathrm{g} / \mathrm{assay} \mathrm{MeOH}$ extract

EA extracts, compared to untreated cells which did not provide a ladder DNA profile (Fig. 2, track a).

\section{Acridine orange (AO)/ethidium bromide (EB) straining}

To examine whether the studied extracts induce apoptosis in B16-F10 cells, we assessed cell morphology using the AO and EB straining method.

Morphologically, cells treated with Nitraria retusa leaves extracts displayed early apoptotic events including membrane blebbing and chromatin condensation. The apoptotic index reached 40, 38, 32 and $37 \%$ treated with different concentration of hex, Chl, $\mathrm{EA}$ and $\mathrm{MeOH}$ extracts respectively (Table 2 ).

Table 2 Apoptotic indexes of B16-F10 cells treated with Nitraria retusa leaf extracts

\begin{tabular}{lll}
\hline Extract & Concentration $(\mu \mathrm{g} / \mathrm{ml})$ & Apoptosis Index $(\%)$ \\
\hline Hexane & 85 & $34 \pm 3^{* * *}$ \\
& 170 & $40 \pm 2^{* * *}$ \\
Chloroform & 340 & $29 \pm 3^{* *}$ \\
& 20 & $38 \pm 2^{* * *}$ \\
& 40 & $32 \pm 2^{* * *}$ \\
Ethyl Acetate & 80 & $30 \pm 1^{* * *}$ \\
& 12.5 & $23 \pm 2^{* *}$ \\
Methanol & 25 & $32 \pm 3^{* * *}$ \\
& 50 & $27 \pm 1^{* *}$ \\
Negative control & - & $23 \pm 3^{* *}$ \\
\hline
\end{tabular}

Values represent the mean +-SD of three separate experiments

The statistical significant of results was evaluated by the Student's $t$-test.

${ }^{*} P<0.05,{ }^{*} P<0.01,{ }^{* * *} P<0.001$ means significant difference between control and treated sample
Effect of Nitraria retusa leaf extracts on melanin synthesis and tyrosinase activity

To investigate the effect of Nitraria retusa leaf extracts on melanin synthesis, B16-F10 melanoma cells were exposed to plant extract at different concentrations for $48 \mathrm{~h}$, and then melanin contents were measured.

In Table 3, results indicate that hexane, chloroforme and ethyl acetate extracts significantly stimulated production of intracellular melanin respectively $29,18.5$ and $18 \mu \mathrm{g} / \mathrm{ml}$ at 340,80 and $50 \mu \mathrm{g} / \mathrm{ml}$ concentration respectively.

Likewise, tyrosinase activity in B16-F10 cells treated with different extracts increases in a time-dependent manner (Fig. 3).

\section{Discussion}

The relationship between concentration of extracts and their antiproliferative effect on B16-F10 cells was investigated by MTT assay. Hex, Chl, EA and $\mathrm{MeOH}$ extracts from Nitraria retusa exhibited an inhibitory effect on B16-F10 cell proliferation in a dose-dependent manner. Chl and EA extracts exhibited the most important antiproliferative activity. However, no cytotoxic effect was

Table 3 Effect of extracts from Nitraria retusa on melanin content in B16-F10 cells after $48 \mathrm{~h}$ incubation

\begin{tabular}{lll}
\hline Extracts & Concentration $(\mu \mathrm{g} / \mathrm{ml})$ & Melanin content $(\mu \mathrm{g} / \mathrm{ml})$ \\
\hline Hexan & 340 & $29^{* * *}$ \\
Chloroform & 80 & $18.5^{* *}$ \\
Ethyl Acetate & 50 & $18^{* *}$ \\
Methanol & 1000 & 12 \\
Negative control & - & 11
\end{tabular}

Values represent the mean +- SD of three separate experiments

The statistical significant of results was evaluated by the Student's $t$-test. ${ }^{*} P<0.05,{ }^{*} P<0.01,{ }^{* * *} P<0.001$ means significant difference between control and treated sample 


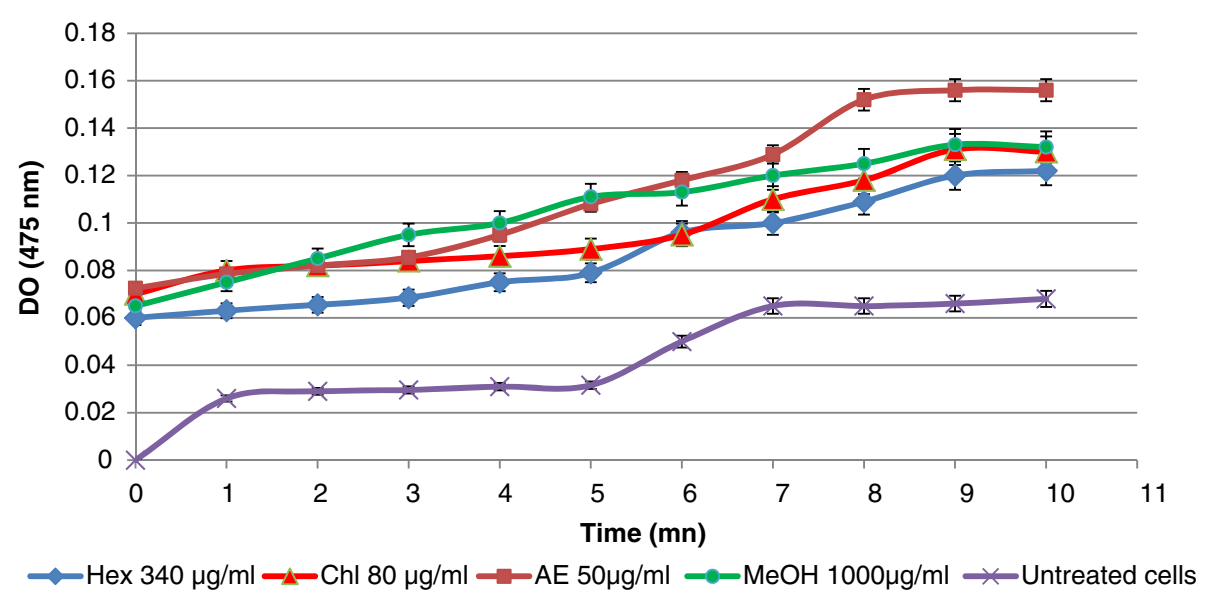

Fig. 3 Effect of Nitraria retusa extracts on tyrosinase activity in B16-F10 cells after $48 \mathrm{~h}$ incubation. Values represent the means \pm SD of three separate experiments. The statistical significance of results was evaluated by the Student's $t$-test. ${ }^{*} P<0.05,{ }^{*} P<0.01,{ }^{* * *} P<0.001$ means significant difference between control and treated sample

observed on primary culture cells (macrophages, splenocytes) when treated with these extracts at the same tested concentrations (data not shown). Likewise, no mortality was recorded when these extracts were administrated by intra-peritoneal injection in mice even at high tested doses $(600 \mathrm{mg} / \mathrm{Kg})$ (data not shown). The cytotoxic activity may be ascribed to the presence of specific components such as polyphenols and flavonoids. As far as our chemical study showed that flavonoids are the main components $[11,20]$ of our extracts, and as it was previously described for their antiproliferative activity against melanoma cells [21-23], we believe that they are responsible at least in part of our extracts antiproliferative potential. However, many authors [24] have reported that minor components may act synergistically and contribute to anti-proliferative effect of tested extracts.

This finding suggest that the anti-proliferative activity of Chl and EA extracts observed in melanoma cells, B16-F10, could be related to apoptosis. Apoptosis is one of the most prevalent pathways through which chemopreventive/ chemotherapeutic agents can inhibit the overall growth of cancer cells [25].

The typical DNA fragmentation pattern which is considered as the hallmark of apoptosis was observed in B16-F10 cells treated with the Chl and EA extracts. As far as the extracts of N.retusa tested in the present study were in crude form and probably contained many compounds which may well act synergistically, it is not possible to say which compounds are responsible for the observed effects. However, our data suggest that the biological effects exhibited by this plant, under these experimental conditions, could be related to an overall effect of the tannins, flavonoids, sterols and coumarins compounds in these extracts $[11,20]$. These results were in agreement with our previous studies that demonstrated how extracts of $N$. Retusa induce DNA fragmentation which observed after $48 \mathrm{~h}$ of incubation with EA extract towards human lymphoblastoid cancer cells, TK6 [20], and with $\mathrm{Hex}, \mathrm{Chl}$ and $\mathrm{MeOH}$ extracts towards human chronic myelogenous erythroleukaemia cells, K562 [11].

The apoptotic potential of Nitraria retusa in B16-F10 cells, was also evaluated by cell morphology using the Acridine Orange/ethidium bromide staining. Morphologically, cells treated with N.retusa leaf extracts displayed early apoptotic events. The viable cells exhibited a green fluorescence (acridine orange staining) whereas apoptotic cells exhibited an orange-red nuclear fluorescence (ethidium bromide staining) by intercalation of ethidium bromide into DNA damage in apoptotic cells. Indeed, cells in early apoptosis still have their intact membranes therefore have the green core, but not uniformly stained, chromatin condensation occurring in them, cleavage of DNA and/or nuclear fragmentation, these are no longer stuck and its morphology was changed, since cells in late apoptosis show chromatin condensation and orange areas in the nucleus, because in the final stages of the process have lost membrane integrity and ethidium bromide on the predominant acridine orange. In the control group we can observe living cells with nuclei well formed and adhered to the blade [26]. The difference of activity when a large excess of the Hex and EA extracts was added to the assay system, could be explained by the inhibition of the penetration through the cell membrane at high doses of extract components [27].

In order to better understand the mechanism involving in inhibition cell gowth of B16 cells we investigated in our study the effect of our extracts on melanogenesis.

In fact, induction of melanogenesis is considered as a well-known marker of differentiated melanoma cells 
[28]. It is also reported that the differentiated melanoma is associated with slower cell proliferation [29].

Thus, in the present study, we provide evidence that $\mathrm{Hex}, \mathrm{Chlo}, \mathrm{EA}$ and $\mathrm{MeOH}$ extracts exposure effectively stimulate tyrosinase activity and melanogenesis in B16F10 melanoma cells in a concentration dependent manner. This effect can be attributed to the presence of phenolic components in these extracts. Indeed, diethylstilbestrol, which is a diphenolic component, is able to enhance melanin synthesis in B16 mouse melanoma cells by activation of the cyclic AMP-protein kinase A pathway and upregulation of expression and activity of the melanogenesis-related enzyme tyrosinase -+ and microphthalmia-associated transcription factor, a transacting factor that regulates the gene transcription of tyrosinase [30]. It is also known that melanin plays an important role in protecting human skin from the harmful effects of UV radiations by absorbing UV sunlight [31]. We can suggest a protective effect of $N$. retusa extracts against skin irritations induced by UV sunlight by enhancing melanogenesis. In fact, as endogenous pigmentation is associated with markedly reduced risk of skin cancer. Agents that enhance skin pigmentation and have the potential to reduce both photodamage and skin cancer incidence took much attention. That's why, evaluation of topically applied substances that simulate natural pigmentation and substances that stimulate the natural pigmentation process become the target of many studies [19, 32].

In fact, these extracts extracts showed a melanogenesis stimulation activity manner in murine B16-F10 melanoma. However, other plant extracts were reported to inhibit melanogenesis [33], and suppressed melanin synthesis [34].

\section{Conclusion}

N.retusa leaf extracts appear to contain compounds with, antiproliferative and apoptotic properties. The three tested extracts induced apoptotic effect by the activation of the extrinsic apoptotic pathway. As apoptosis has become a new therapeutic target in cancer research, it appears reasonable to suggest that N.retusa may have potential as an agent of chemotherapeutic and cytostatic activity in murin cancer cells. The tested extracts were also able to induce melanin synthesis and tyrosinase activity and thus the differenciation of B16F10 cells.

\section{Abbreviations \\ DNA: Deoxyribonucleic acid; Hex: Hexane; Chl: Chloroform; MeOH: Methanol;} DMSO: Dimethyl sulfoxide; AO: Acridine orange; EB: Ethidium bromide.

\section{Competing interests}

The authors declare that they have no competing interests and non-financial competing interests.

\section{Authors' contributions}

BJ: Was responsible for the conception and design, testing and data acquisition, analysis and data interpretation and drafted the manuscript. IMB: made contribution to the phytochemical study. NN: made contribution to the cellular study. BGH: made contribution to data interpretation and drafted the manuscript. MN: made contribution to data interpretation and drafted the manuscript. GK: made substantial contribution to conception and revised it critically for importantintellectual content. CGL: made substantial contribution to conception and revised it critically for important intellectual content. All authors read and approved the final manuscript.

\section{Acknowledgements}

The authors acknowledge the "Ministry of Higher Education, Scientific Research and Technology, Tunisia", for the support of this study and also thank Mr. Samir Boukattaya (Pr. Of English at the faculty of Dental Medicine,Tunisia) for English editing.

\section{Author details}

${ }^{1}$ Laboratory of Cellular and Molecular Biology, Faculty of Dental Medicine, University of Monastir, Rue Avicenne, Monastir 5000, Tunisia. ${ }^{2}$ Unity of bioactive natural substances and biotechnology, Faculty of Pharmacy, University of Monastir, Rue Avicenne, Monastir 5000, Tunisia. ${ }^{3}$ Higher Institute of Medical Technologies of Tunis, Tunis El Manar University, Tunis El Manar 2092, Tunisia.

Received: 16 December 2014 Accepted: 24 June 2015

Published online: 02 September 2015

\section{References}

1. Ivanova D, Gerova D, Chervenkov T, Yankova T. Polyphenols and antioxidant capacity of Bulgarian medicinal plants. Journal of Ethnopharmacology. 2005:96:145-50.

2. Yaar M, Wu C, Park HY, Panova L, Schutz G, Gilchrest BA. Bone morphogenetic protein-4, a novel modulator of melanogenesis. J Biol Chem. 2006:281:25307-14.

3. Miyazawa M, Tamura N. Inhibitory compound of tyrosinase activity from the sprout of Polygonum hydropiper L. (Benitade). Biological and Pharmaceutical Bulletin. 2007;30:595-7.

4. Zhong S, Wu Y, Soo-Mi A, Zhao J, Wang K, Yang S, et al. Depig- mentation of melanocytes by the treatment of extracts from traditional Chinese herbs: a cell culture assay. Biological and Pharmaceutical Bulletin. 2006;29:1947-51.

5. Goleniowski ME, Bongiovanni GA, Bongiovanni L, Palacio CO, Cantero JJ. Medicinal plants from the "Sierra de Comechingones". Argentina Journal of Ethnopharmacology. 2006;107:324-41.

6. Maas JL, Galletta GJ. Ellagic acid, an anticarcinogen in fruits, especially in strawberries: a review. Hort Sci. 1991;26:10-4.

7. Samina N, Russell GK, Ramaswamy N. New antiproliferative epoxysecosterols from Pseudopterogorgia Americana. Tetrahedron Lett. 2000:41:6035-40.

8. Hannum SM. Potential impact of strawberries on human health a review of the science. Crit Rev Sci Nutr. 2004:44:1-7.

9. Hoang MT, Eichenfield LF. The rising incidence of melanoma in children and adolescents. Dermatol Nurs. 2000;12(188-189):183-92.

10. Rao YK, Madamanchi G, Shih-Hua F, Yew-Min. Antioxidant and cytotoxic activities of naturally occurring phenolic and related compounds: a comparative study. Food Chem Toxicol. 2007;45:1770-6

11. Boubaker J, Bhouri W, Ben Sghaier M, Bouhlel I, Skandrani I, Ghedira K, et al. Leaf extracts from Nitraria retusa promote cell population growth of human cancer cells by inducing apoptosis. Cancer Cell International. 2011 doi:10.1186/1475-2867-11-37.

12. Alesiani D, Cicconi R, Mattei M, Montesano C, Bei R, Canini A. Cell cycle arrest and differentiation induction by 5,7-dimethoxycoumarin in melanoma cell lines. Int J Oncol. 2008;32:425-34

13. Pottier-Alapetite G. Flowers of Tunisia: Angiosperms, dicotyledons, apetals, dialypetals Tunisia. Tunisia: Ministry of higher Educationb and Scientific Research and the Ministry of Agriculture; 1979. p. 456.

14. Cheib M, Boukhris M. Flora succint and illustrated flora of the arid zone and Sahara of Tunisia. Tunisia official printing house. 1998; 49:43-44.

15. Boubaker J, Skandrani I, Bouhlel I, Ben sghaier M, Neffati A, Ghedira K, et al. Mutagenic, antimutagenic and antioxidant potency of leaf extracts from Nitraria retusa. Food and Chem Toxicol. 2010:48:2283-90.

16. Carmichael J, DeGraff WG, Gazdar AF, Minna JD, Mitchell JB. Evaluation of a tetrazolium-based semiautomated colorometric assay; assessment of chemosensitivity testing. Cancer Res. 1987;47:936-42. 
17. Wang IK, Lin-Shiau SY, Lin JK. Induction of Apoptosis by Apigenin and Related Flavonoids Through Cytochrome c Release and Activation of Caspase-9 and Caspase-3 in Leukaemia HL-60 Cells. European Journal of Cancer. 1999;35(10):1517-25.

18. Twentyman PR, Fox NE, Rees JK. Chemosensitivity testing of fresh leukaemic cells using the MTT colourimetric assay. Br J Haematol. 1989;71:19-24.

19. Skandrani I, Pinon A, Simon A, Ghedira K, Chekir-Ghedira L. Chloroform extract from Moricandia arvensis inhibits growth of B16-F0 melanoma cells and promotes differentiation in vitro. Cell Proliferation. 2010;43:471-9.

20. Boubaker J, Bhouri W, Ben Sghaier M, Bouhlel I, Kriffi M, Skandrani I, et al. Flavonoids Products from Nitraria retusa Leaves Promote Lymphoblastoid Cells Apoptosis. Nutrition and Cancer. 2012;64(7):1095-102.

21. Martinez C, Yañez J, Rodríguez J, Canteras M, Alcaraz M, Vicente V. Inhibicion del crecimiento de la lınea de melanoma B16-F10 por diferentes compuestos polifeno'licos. Revista Española de Patología. 2001;34:317-24

22. Yanez J, Martınez C, Rodrıguez J, Canteras M, Alcaraz M, Vicente V. Efecto de seis flavonoides sobre el crecimiento de la lınea de melanoma humano SK. Mel-1. Oncologia. 2002;25:210-6.

23. Skandrani I, Ben Sghaier M, Neffati A, Boubaker J, Bouhlel I, Kilani S, et al. Antigenotoxic and free radical scavenging activities ofextracts from Moricandia arvensis. Drug Chem Toxicol. 2007;30:361-82.

24. Yu JQ, Lei JQ, Yu HD, Cai X, Zou GL. Chemical composition and antimicrobial activity of essential oil of Scutellaria barbata. Phytochemistry. 2004:65:881-4.

25. Reed JC, Pellecchia M. Apoptosis-based therapies for hematologic malignancies. Blood. 2005:106:408-18

26. Machado KE, Oliveira KN, Santos-Bubniak L, Licínio MA, Nunes RJ, SantosSilva MC. Evaluation of apoptotic effect of cyclic imide derivatives on murine B16F10 melanoma cells. Bioorganic \& Medicinal Chemistry:. 2011;19:6285-91.

27. Skandrani I, Bouhlel I, Limem I, Boubaker J, Bhouri W, Neffati A, et al. Ghedira-Chekir I: Moricandia arvensis extracts protect against DNA damage, mutagenesis in bacteria system and scavenge the superoxide anion. TIV. 2009;23:166-75.

28. Edward M, Gold JA, MacKie RM. Different susceptibilities of melanoma cells to retinoic acid-induced changes in melanotic expression. Biochemical and Biophysical Research Communications. 1988:155:773-8.

29. Puri N, Eller MS, Byers HR, Dykstra S, Kubera J, Gilchrest BA. Telomerebased DNA damage responses: a new approach to melanoma. FASEB Journal. 2004;18:1373-81.

30. Jian D, Jiang D, Su J, et al. Diethylstilbestrol enhances melanogenesis via CAMP-PKA-mediating up-regulation of tyrosinase and MITF in mouse B16 melanoma cells. Steroids. 2011;76:1297-304.

31. Solano F, Briganti S, Picardo M, Ghanem GH. Hypopigmenting agents: an updated review on biological, chemical and clinical aspects. Pigm Cell Res. 2006;19:550-71.

32. Chaabane F, Pinon A, Simon A, Ghedira K, Chekir-Ghedira L. Phytochemical potential of Daphne gnidium in inhibiting growth of melanoma cells and enhancing melanogenesis of B16-F0 melanoma. Cell Biochem Funct. 2012. doi:10.1002/cbf.2919.

33. Nakashima S, Matsuda H, Oda Y, Nakamura S, Xu F, Yoshikawa M. Melanogenesis inhibitors from the desert plant Anastatica hierochuntica in B16 melanoma cells. Bioorganic and Medicinal Chemistry. 2010;18:2337-45.

34. Nguyen DH, Nguyen DTM, La LH, Yang SH, Lee HB, Kim HJ, et al. Depigmenting effect of Cinnamomum cassia Presl in B16-F10 melanoma cells. Korean Journal of Chemical Engineering. 2007;24:827-30.

\section{Submit your next manuscript to BioMed Central and take full advantage of:}

- Convenient online submission

- Thorough peer review

- No space constraints or color figure charges

- Immediate publication on acceptance

- Inclusion in PubMed, CAS, Scopus and Google Scholar

- Research which is freely available for redistribution 